\title{
The Implementation of Batik Besurek Motif for Geometric Transformation Learning
}

\author{
Syalendra Putra*
}

\author{
SMK Negeri 6 Seluma, Bengkulu, Indonesia \\ *Corresponding author. Email: syatra84@gmail.com
}

\begin{abstract}
With a combination of Arabic calligraphy motifs, Batik Besurek is a traditional Bengkulu's patterned cloth with Rafflesia flowers as a symbol of the Bengkulu region. This study will investigate Batik Besurek motif implementation, specifically geometric transformation content, for mathematics learning. Design research is this form of research. The design research phases, namely: Preparing for the Experiment, Teaching Experiment, and Retrospective Analysis The study consisted of 32 randomly chosen students in class XI SMA. Tests and questionnaires are data collection methods. Questionnaires have been used to evaluate the performance, efficiency, and practicality of learning mathematics by applying the Batik Besurek motif. Descriptive statistics and t-tests have been used to evaluate test results. The findings showed that the Batik Besurek motif enhanced geometric transformation learning outcomes and positively responded to students.
\end{abstract}

Keywords: Batik Besurek, Mathematics, Geometric transformation, Motif.

\section{INTRODUCTION}

The mapping points in an image to an object to form another image is a transformation in mathematics learning. The shape of the image can be shifted anywhere, above, below, left, or right during transformation. It is also possible to rotate the image in any direction. Transformation is very important to learn in school because other principles, such as function and symmetry, are based on transformation [1]. Geometric transformation allows students to discuss geometric concepts in an informal and intuitive approach. Sensitivity, conjecture, transformation, and interest are highlighted by this approach [2]. Geometric transformations can be performed in four basic transformation forms: translation, rotation, reflection, and dilation. Lestariningsih dan Mulyono also states that by reflection, translation, rotation, or dilation, transformation is converting an original geometric image or shape into a new image [3].

The findings of Clements \& Burns and Rollick's research suggest that it is difficult for many students to recognize ways of transformation such as translation, reflection, and their combinations [4,5]. As Lestariningsih and Mulyono note, transformation is difficult since a picture that shifts through reflection, translation, rotation, or dilation needs an understanding of it [3]. Research conducted by Morris and Paulsen showed that some students could transform simple geometric artifacts, but for more complex forms, they had trouble finding rotation and reflection issues [6]. Also, students also have trouble creating evidence of algebraic-geometric transformations [7]. To increase the capacity of mathematical evidence, algebraic evidence that is a general proof is very important. Albab et al. reported that many students have not been able to generalize that image of point $A^{\prime}(x,-y)$ would be generated by the reflection of point $\mathrm{A}(\mathrm{x}, \mathrm{y})$ to the $\mathrm{X}$-axis [8]. Simultaneously, the geometry material of transformation is very useful for students to understand the nature of geometry through an informal approach that students can imagine to enhance their spatial abilities [9]. According to NCTM, learning programs ranging from kindergarten to high school must allow students to analyze mathematical problems using transformation and symmetry [10].

The fact shows that more than half of high school mathematics teachers in Bengkulu use whiteboard media to perform traditional geometric transformation learning. The media is known to be the easiest and simplest to use. The teacher's practice of writing on the blackboard and erasing the writing again is more spent on learning, and students behave as successful note-takers. The teacher does not think about whether the given geometric transformation content is abstract or requires more visual clarification.

Students study actual objects to accept the idea of abstract geometric transformation as an intermediary or visualization. Tools are required that can promote the visual representation of geometric transformations for students. This is in line with what Özerem said that the use of visual aids by teachers to be able to teach geometric transformation content in more detail is one of the solutions to resolve the errors created by learners in learning geometric 
transformation [11]. This is similar to the results of Thaqi, who also concluded in his research that with the aid of photographs, educators were better able to teach transition geometry [12]. He argued that students should discover the properties of transformational images through visuals to research transformation.

Meanwhile, according to Naidoo, a mixture of visual and analytical is the most powerful method in learning geometric transformation [7]. Visual and theoretical support methods should be carried out for students so they can think abstractly. So we need advancement in learning that can link mathematical principles with students' visual experiences in daily life. We need a cultural and intellectual development base in education [13]. One of them is the visual application of cultural values and local wisdom, such as Batik Besurek Bengkulu, to mathematical learning. As Widjaja \& Fauzan have discovered, meaningful sense generates student mathematical thinking and debate [14]. This is in line with Torres-Velasquez and Lobo's finding that by linking mathematics material with culture and real-life in student interactions, teachers need to contextualize mathematics learning [15].

Batik is a pictorial cloth produced specifically by writing wax on the cloth. Then the printing is processed in a way that has specificity and a certain coloration. Batik is a traditionally crafted piece of fabric. Dullah has several decorative patterns and some patterns made as a color barrier material using a special wax writing technique [16]. Since October 2, 2009, Batik in Indonesia has been designated by UNESCO as a masterpiece of humanity's oral and intangible heritage. Batik Besurek Bengkulu is one of the popular Batiks of Indonesia.

There is a distinctive characteristic of the Bengkulu Besurek Batik motif, namely the Arabic calligraphy writing combined with the Rafflesia Arnoldi flower [17]. Also, Batik Besurek's creations have been created to add to the beauty and enhance Batik Besurek's quality, including the motif of the living tree, moon motif, motif of the mussel flower, motif of the nail niche, motif of the Cempaka flower, etc. If Batik shapes are found, there are features of rhythmic or patterned regularity [18]. Batik regularity is a type of geometric transformation by translation, rotation, reflection, or dilation in this case.

\section{METHOD}

Design research is this form of research. The research phases followed the design research phases suggested by Gravemeijer and Cobb: Preparing for the Experiment, Teaching Experiment, and Retrospective Analysis [19]. A Hypothetical Learning Trajectory (HLT) design was developed along with testing tools at the Preparing for the Experiment level. The benchmark for making learning resources is HLT. HLT serves as a guide for teachers during the teaching experiment stage to teach learning materials, carry out assessments of learning outcomes, and perform interviews. HLT serves as a guideline for the study of learning results at the retrospective analysis level.

The study sample consisted of 32 students chosen randomly from Class XI high school students in Bengkulu Province. Tests and questionnaires are data collection methods - a test consisting of 15 item questions that were tested on students. While questionnaires were used to obtain student response data after learning by applying the Batik Besurek Bengkulu motif, the test was performed to obtain data on learning outcomes of geometric transformations. To evaluate the efficiency, performance, and learning practices, the questionnaire data were analyzed descriptively. The following hypotheses were used to prove the significance of differences in learning outcomes. The learning outcome data were analyzed using the t-test:

$\mathrm{H}_{0}$ : After applying the Batik Besurek motif, the average learning outcomes are lower or the same as the learning outcomes before applying the Batik Besurek motif.

$\mathrm{H}_{1}$ : After applying the Batik Besurek motif, the average learning results are higher than the learning outcomes before applying the Batik Besurek motif.

Error level $\alpha=0,05$

\section{RESULTS AND DISCUSSION}

A literature review for Geometric Transformation and Bengkulu Batik Besurek motifs was performed at the Preparing for the Experiment stage. Also, a Hypothetical Learning Trajectory was made, and experts test the material and initial learning design. Besides, HLT is revised based on expert recommendations to be developed into the final learning design.

Based on the test results, the initial average student score before applying the Besurek Bengkulu batik motif in mathematics learning in Geometry Transformation material was 59,03125. After applying the Besurek Bengkulu batik motif in Geometric Transformation material in mathematics learning, the final average student score was 77,8125 . There were 26 students out of the 32 students who scored $\geq 70$. So, 81.25 percent was the percentage of classical completeness

Four tasks consisted of the teaching experiment stage. In the first activity, students observe the Bengkulu Besurek batik motif found on one of the clothes in the first activity (figure 1). Then the students search for the primary or basic motive of the clothing. Also, students communicate with the teacher their results. 


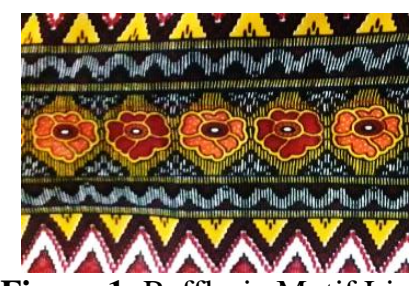

Figure 1. Rafflesia Motif Line

1) Students get the basic form of the motif above, like this:

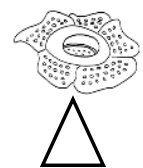

2) The pattern on the motif above can be seen as the result of a translation of the basic form

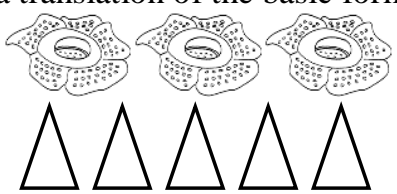

3) It is added to these questions after discovering the Batik pattern. Point R $(3,2)$ moves 5 steps to the left and 1 step down. How to draw the movement on the Cartesian coordinate plane of this point? The point's starting position is $\mathrm{R}(3,2)$ and then moves 5 steps to the left and 1 step down so that $\mathrm{R}^{\prime}(-2,1)$ shifts the position. It implies:

$$
\left(\begin{array}{l}
3 \\
2
\end{array}\right)+\left(\begin{array}{l}
-5 \\
-1
\end{array}\right)=\left(\begin{array}{c}
-2 \\
1
\end{array}\right)
$$

So, after the move, the final position of $\mathrm{R}$ is R'(2,1)

In the second activity, students paid attention to the Bengkulu Batik Besurek motif below:

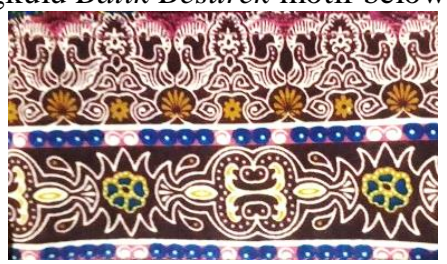

Figure 2. Rafflesia and Nail Niche Motif for Creation

1) Students get the basic form of the motif above, like this:

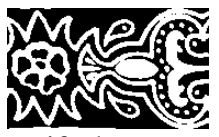

2) The pattern on this motif above can be seen as a result of reflecting on the basic form of the vertical line or the $y$-axis

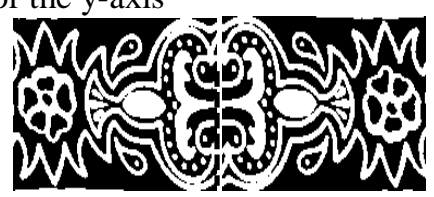

3) It is added to these questions after discovering the Batik pattern. Point R $(-3,2)$ is reflected on the $y-$ axis, and how is the Cartesian coordinate plane sketch of the motion of this point? The point's starting position is $\mathrm{R}(-3,2)$, reflected on the $\mathrm{Y}$ axis, so that $R^{\prime}(3,2)$ changes in position. This implies that $\mathrm{R}(\mathrm{x}, \mathrm{y})$ transitions to $\mathrm{R}^{\prime}(-\mathrm{x}, \mathrm{y})$ when expressed on the $\mathrm{Y}$-axis.

In the third activity, students paid attention to the Bengkulu Batik Besurek motif below:

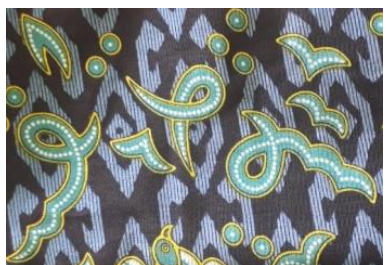

Figure 3. Arabic Calligraphy Motif

1) Students get the basic form of the motif above, like this:

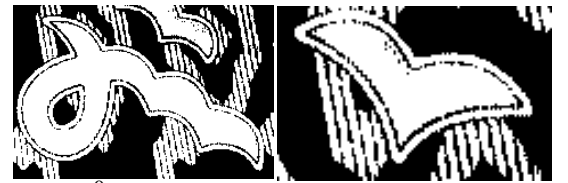

2) In addition, $90^{\circ}$ clockwise rotates the larger base motif, and $180^{\circ}$ clockwise rotates the smaller base motif to obtain:
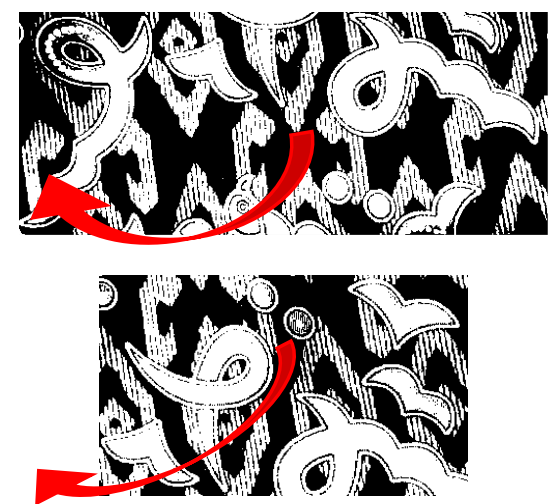

3) It is added to the questions after discovering the Batik pattern. Point R $(-3,2)$ is rotated $90^{\circ}$ in the clockwise direction centered at the location $(0,0)$. How to draw the motion of this point on the plane of the Cartesian coordinate? $\mathrm{R}(-3,2)$ rotated 90 clockwise centered at the point $(0,0)$ is the starting position of the point, so that the position changes at $\mathrm{R}^{\prime}(2,3)$. This implies that $\mathrm{R}(\mathrm{x}, \mathrm{y})$ transforms into $\mathrm{R}^{\prime}(\mathrm{y},-\mathrm{x})$ when rotated 90 clockwise centered at the point $(0,0)$.

In the fourth activity, students paid attention to the Bengkulu Batik Besurek motif below: 


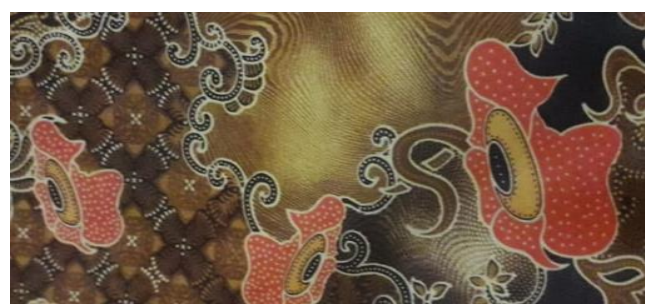

Figure 4. Rafflesia Flower Motif

1) Students get the basic form of the motif above, like this:

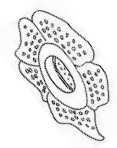

2) The pattern on the motif above can be seen as the result of dilation of the basic form

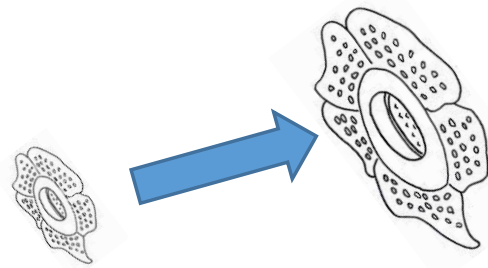

3) It is added to the questions after discovering the Batik pattern. The triangle $\mathrm{ABC}$ is dilated to the center point $(0,0)$ with a scale factor of 2 , with the coordinates of each point $\mathrm{A}(2,2), \mathrm{B}(3,2)$, and $\mathrm{C}(2,3)$. How to draw the changes in the triangle on the Cartesian plane? The starting position of points $\mathrm{A}(2,2), \mathrm{B}(3,2)$, and $\mathrm{C}(2,3)$ is dilated to the center point $(0,0)$ with a scale factor of 2 to shift the position of points $\mathrm{A}(4,4), \mathrm{B}(6,4)$ and $\mathrm{C}(4,6)$. This means that point $\mathrm{A}(\mathrm{x}, \mathrm{y})$ changes to $\mathrm{A}^{\prime}(\mathrm{kx}$, $\mathrm{ky})$ if it is dilated to the center point $(0,0)$ with a scale factor of $\mathrm{k}$.

Students' real learning experiences were compared with the previously prepared learning designs in the retrospective analysis stage. At this point, both in terms of learning output and learning effectiveness, data analysis obtained from the mathematics learning process is carried out. A reconstruction and revision of the learning design were often done at this point, which can have repercussions for the wider context and situation.

Based on the student answer questionnaire evaluation results for the learning performance component, it was found that the average student evaluation for a scale of 1 to 4 was 3.5. This indicates that the geometric transformation learning output applied to the Batik Besurek motif is good and feasible to use.

Based on the student questionnaire evaluation results for the efficiency aspect, it was found that the average student evaluation was 3.47. This indicates that it is efficient to learn geometric transformations applying the Batik Besurek Bengkulu motif. Likewise, the average student assessment was 3.6 for the practical aspect. This indicates that it is more realistic to learn geometric transformations that apply the Batik Besurek Bengkulu motif.

It was found that the $t$ count was 32,769 , and the $t$ table was 1,753 for $\alpha=0,05$ based on the results of the t-test tested on 32 students of class XI SMA. The $t$ count $>t$ table is known from the $t$-test, so Ho is rejected. Since t count $>\mathrm{t}$ table, it can be concluded that after applying the Bengkulu Batik Besurek motif in Geometric Transformation learning, the average student learning results are significantly higher than the average student learning results before applying the Bengkulu Batik Besurek motif in Geometric Transformation learning

They were acquiring good performance, efficiency, effectiveness, and practicality of learning. According to student creativity, students can take advantage of Bengkulu Batik Besurek motifs by rotating, moving, reflecting, enlarging, and reducing. This is like research conducted by Lubis \& Yanti, which shows congruent concepts in the Bengkulu batik Besurek, which are aspects of geometry [20]. Yanti also notes that, including symmetrical geometry and transformation principles, the Bengkulu batik Besurek incorporates mathematical elements [21]. The concepts of reflection, translation, rotation, and dilation are also present in Yogyakarta batik motifs, apart from the Besurek cloth motif [22]. Design students can easily learn the geometric transformation concept from batik motifs because the motif is familiar in everyday life. The notion of translation and dilation is also found in the ornament called Gogra of the Batak tribe [23].

The motif of Bengkulu Besurek Batik and other Batik motif regions enables students to visualize ways of geometric transformation to help students understand geometric transformation. Furthermore, since it is made from a mixture of the Bengkulu Batik Besurek motif, mathematic learning becomes more appealing.

\section{CONCLUSIONS}

This research shows that after being introduced to the Batik Besurek motif, the average student learning results are substantially higher than before applying the Batik Besurek motif. Based on the answers to students' questionnaires, performance, efficiency, and practicality of learning mathematics by applying the Batik Besurek motif are high. Besurek batik motif allowed learners to imagine ways of geometric transformation to help students understand the principle of geometric transformation (translation, rotation, reflection, or dilation) and can eventually enhance mathematics learning outcomes for geometry transformation material.

\section{REFERENCES}

[1] Hollebrands, K. F. High school students' understanding of geometric transformations in the context of a technological environment. 
Journal of Mathematical Behavior. 2003. 22, 55-72. http://dx.doi.org/10.1016/S07323123 (03)00004-X

[2] Novrika, Dina dll. Desain Pembelajaran Materi refleksi Menggunakan Motif Kain Batik untuk Siswa Kelas VII. Prosiding Seminar Matematika dan Pendidikan Matematika FKIP UNS. 607-626, 2016.

[3] Lestariningsih dan Mulyono, Imam Mulyono. Desain Pembelajaran Transformasi Menggunakan Motif Batik Tulis Sidoarjo. Jurnal Edukasi, Volume 3 No.1, April 2017.

[4] Clements, D. H. \& Burns, B. A. Students' development of strategies for turn and angle measure. Educational Studies in Mathematics, 2000. 41(1), 31-45.

[5] Rollick, M. B. Toward a definition of reflection. Journal of Mathematics Teaching in the Middle School, 2009. 14(7), 396-398.

[6] Morris, T. \& Paulsen, R. Using Tracing Paper to Teach Transformation Geometry. Amesa, Vol. 2. 2011. Johannesburg: Amesa.

[7] Naidoo, J. Strategies Used by Grade 12 Mathematics Learners in Transformation Geometry. 2010. Natal: University of Kwazulu.

[8] Albab, Irkham Ulil dkk. Kemajuan Belajar Siswa pada Geometri Transformasi Menggunakan Aktivitas Refleksi Geometri. Jurnal Cakrawala Pendidikan, Oktober 2014, Th. XXXIII, No. 3

[9] Guvent, Bulente. Using Dynamic Geometry Sofware to Improve Eight Grade Students' Understanding of Transformation Geometry, Australian Journal of Educational Technology. 2012. 28(2). 364-382.

[10] NCTM. Principles and Standards for School Mathematics: Electronic Examples. 2000

[11] Özerem, A. (2012). Misconceptions In Geometry And Suggested Solutions For Seventh Grade Students. International Journal of New Trends in Arts, Sports \& Science Education, 1(4). Accessed on February 28, 2014 from https://www.sciencedirect.com/science/article/ pii/S1877042812040190

[12] Thaqi, X. dan Gimenez, J. Prospective Teacher's Understanding of Geometric Transformation. 12th International Congress on Mathematical Education. 2012. Seoul: TSG10.
[13] Maseleno, Andino et al. General Theoretical and Philosophical Aspects of Modern Education. Revista San Gregorio, August 2019, No. 32.

[14] Widjaja, W, \& Fauzan, A. The Role of Contexts and Teacher's Questioning to Enhance Students' Thinking. Journal of Science and Mathematics Education in Southeast Asia, 2010. 33(2), 168-186.

[15] Torres-Velasquez, D., \& Lobo, G. Culturally responsive mathematics teaching and English language learners. Teaching Children Mathematics, 2004. 11, 249-255.

[16] Dullah, Santoso. Batik, Pengaruh Zaman dan Lingkungan. Solo: Danar Hadi. 2002.

[17] Sanaran, Idrus dkk. Kerajinan Kain Besurek. 1998. Solo: Tiga Serangkai

[18] Cempaka, Rizeta Suci dkk. Kreativitas Belajar Matematika Siswa Pada Materi Geometri Transformasi Berbasis Batik Pekalongan. Makalah pada Seminar Nasional Matematika dan Pendidikan Matematika 12 Mei 2018, Purworejo: Universitas Muhammadiyah Purworejo

[19] Gravemeijer dan Cobb. Design Research from A Learning Design Perspective. Dalam Akker, Gravemeijer, McKenney dan Nieveen. Educational Design Research. 2006. London: Routledge.

[20] Lubis, A. N. M. T., \& Yanti, D. Identifikasi Etnomatematika Batik Besurek Bengkulu Sebagai Media Dan Alat Peraga Penyampaian Konsep Kekongruenan Dan Kesebangunan. 2018. Wahana Didaktika, 16(3), 267-275.

[21] Yanti, D. Eksplorasi etnomatematika batik besurek Bengkulu sebagai nilai filosofi dan konsep matematis. Prosiding seminar nasional megister pendidikan dasar 2017. FKIP Universitas Bengkulu, 105-112.

[22] Risdiyanti, I., \& Prahmana, R. C. I.. Ethnomathematics: Exploration in Javanese culture. Journal of Physics: Conference Series 943(1), 012032. 2017 December. IOP Publishing

[23] Ditasona, C. Ethnomathematics Exploration of the Toba Community: Elements of Geometry Transformation Contained in Gorga (Ornament on Bataks House). IOP Conference Series: Materials Science and Engineering 2018. 335(1), 012042. IOP Publishing. 